\title{
Correction: Comparative genomic profiling of Dutch clinical Bordetella pertussis isolates using DNA microarrays: identification of genes absent from epidemic strains
}

\author{
Audrey J King ${ }^{1 *}$, Tamara van Gorkom', Jeroen LA Pennings'², Han GJ van der Heide', Qiushui He³,
} Dimitri Diavatopoulos ${ }^{4}$, Kees Heuvelman ${ }^{1}$, Marjolein van Gent ${ }^{1}$, Karin van Leeuwen ${ }^{1}$, Frits R Mooi ${ }^{1}$

\section{Correction}

After the publication of this work [1] we found out that Table 1 was not filled in correctly in the original article. The total number of strains analyzed in the $\operatorname{ptxP} 1$ or the $p t x P 3$ lineage was not shown between the brackets, leading to incompleteness of the data. The revised Table 1 is shown below.

We regret any inconvenience that the incompleteness of Table 1 in the original article might have caused.

\begin{abstract}
Author details
'Laboratory for Infectious Diseases and Screening (LIS) Centre for Infectious Disease Control, National Institute for Public Health and the Environment (RIVM), Bilthoven, The Netherlands. '2 Laboratory for Health Protection Research, National Institute for Public Health and the Environment (RIVM), Bilthoven, The Netherlands. ${ }^{3}$ Pertussis Reference Laboratory, National Public Health Institute, Finland. ${ }^{4}$ Department of Microbiology and Immunology, University of Melbourne, Victoria, Australia.
\end{abstract}

Received: 19 March 2010 Accepted: 24 March 2010

Published: 24 March 2010

\section{References}

1. King AJ, van Gorkom T, Pennings JL, van der Heide HG, He Q,

Diavatopoulos D, et al: Comparative genomic profiling of Dutch clinical Bordetella pertussis isolates using DNA microarrays: identification of genes absent from epidemic strains. BMC Genomics 2008, 9:311.

doi:10.1186/1471-2164-11-196

Cite this article as: King et al:: Correction: Comparative genomic profiling of Dutch clinical Bordetella pertussis isolates using DNA microarrays: identification of genes absent from epidemic strains. BMC Genomics 2010 11:196.

\footnotetext{
* Correspondence: Audrey.King@rivm.nl

${ }^{1}$ Laboratory for Infectious Diseases and Screening (LIS) Centre for Infectious Disease Control, National Institute for Public Health and the Environment (RIVM), Bilthoven, The Netherlands
}

Submit your next manuscript to BioMed Central and take full advantage of:

- Convenient online submission

- Thorough peer review

- No space constraints or color figure charges

- Immediate publication on acceptance

- Inclusion in PubMed, CAS, Scopus and Google Scholar

- Research which is freely available for redistribution

Submit your manuscript at

www.biomedcentral.com/submit

C) Biomed Central 
Table 1 Presence of regions of difference in Dutch clinical isolates from 1993 to 2004

\begin{tabular}{|c|c|c|c|c|c|}
\hline Region of difference & BP-number & $\begin{array}{l}\text { No. of } \\
\text { genes }\end{array}$ & Size & ptxP1 lineage & ptxP3 lineage \\
\hline Locus: & & & (kb) & & \\
\hline$R D-3$ & BP0910A-BР0937 & 23 & 24.9 & $0 \%(17)$ & $0 \%(26)$ \\
\hline$R D-5$ & BP1135-BP1141 & 7 & 8.6 & $0 \%(17)$ & $0 \%(26)$ \\
\hline$R D-6$ & BP1158-BP1176 & 19 & 18.7 & $94 \%(17)$ & $100 \%(26)$ \\
\hline$R D-27$ & BP1553 & 1 & 0.8 & $82 \%(17)$ & $100 \%(26)$ \\
\hline$R D-10$ & BP1948-BP1966 & 18 & 22.7 & $100 \%(27)$ & $0 \%(53)$ \\
\hline$R D-28$ & BP2122-BP2123 & 2 & 1.7 & $94 \%(17)$ & $100 \%(26)$ \\
\hline$R D-29$ & BP2822-BP2839 & 17 & 16.9 & $94 \%(17)$ & $100 \%(26)$ \\
\hline$R D-18$ & BP3314-BP3322 & 9 & 9.4 & $94 \%(17)$ & $92 \%(26)$ \\
\hline$R D-1^{*}$ & BP0515-BP0516 & 2 & 1 & $0 \%(17)$ & $13 \%(32)$ \\
\hline
\end{tabular}

Regions of difference (RDs) are numbered according to Brinig et al [23]. RD-1* is part of RD-1 as was found by Brinig et al [23]. The percentage of strains harbouring the region and the number of strains analyzed are indicated. Size, refers to the size of the deletion. 